\title{
EL CINE COMO INSTRUMENTO DE ALFABETIZACIÓN EMOCIONAL
}

\section{The cinema like instrument of emotional alphabetization}

\section{Le cinéma comme instrument d'alphabétisation émotionnelle}

M. ${ }^{a}$ del Carmen Gutiérrez Moar* ${ }^{*}$. ${ }^{a}$ del Carmen Pereira Domínguez** y

Luis Fernando VALERO IGLESIAs**

*Universidad de Santiago de Compostela. Facultad de Ciencias de la Educación. Departamento de Teoría de la Educación, Historia de la Educación y Pedagogía Social. Campus Sur. 15782 Santiago de Compostela. Correo-e: bemarygu@usc.es **Universidad de Vigo. Facultad de Ciencias de la Educación. Departamento de Análisis e Intervención Psicosocioeducativa. Avda. Castelao, s/n. Campus Ourense. 32004 Ourense. Correo-e: mcdguez@uvigo.es

${ }^{* * *}$ Universidad Rovira $i$ Virgili. Facultad de las Ciencias de la Educación y Psicología. Departamento de Pedagogía. Carretera de Valls, s/n. 43007 Tarragona. Correo-e: luis.valero@urv.net

Fecha de recepción: enero de 2006

Fecha de aceptación definitiva: abril de 2006

BIBLID [(1130-3743) 18, 2006, 229-260]

RESUMEN

A menudo se ha identificado la educación, sobre todo la formación en las instituciones educativas, con una visión de la persona en la que la razón se convierte en criterio y control de todo. Y por ello sólo se ha pretendido trabajar con los conocimientos para una inteligencia separada de todo lo que a una persona la convierte en humana, en ser vivo que siente, se alegra, sufre. 
En ese sentido, lo emocional ha sido (o es) infravalorado, cuando no visto como sospechoso o temible. (Quizás también por esa represión, luego se producen estallidos brutales del mundo emocional-pasional). Sin embargo, la persona es un ser llamado a integrar sus dimensiones cognoscitivas, emocionales y volitivas. Y prestigiosos psicólogos contemporáneos han demostrado esa integración en sus estudios sobre inteligencia emocional.

Por eso, en este artículo, se trata de recoger las nuevas concepciones sobre la emoción y su lugar en la persona humana y presentar una forma de vincularla a la educación, a la formación en valores, a través de un medio, el cine, que llega directamente a lo emocional de la persona pero que está llamado a ser recibido por la totalidad de la persona y aprovechado como un mensaje, una comunicación de educación y cultura.

Palabras clave: educación, emoción, alfabetización emocional, educación en valores, intervención pedagógica, lenguaje cinematográfico.

\section{SUMMARY}

Education often has been identified, above all the information in the educational institutions, with a view of a person where the reason turns into the rule and control of everything. Therefore it has expected to work with the knowledge for a intelligence separated from everything that turns a person into human, into a living being that feels, is glad, suffers.

In this way, the emotional sight has been underestimated when it has not been seen as suspicious or fearsome. (Maybe the reason is the repression, then the emotional and passionate world tremendously explodes). However, the person so-called to compose his cognitive, emotional and volutive dimensions. And prestigious contemporary psychologists have shown that integration in their emotional intelligence studies.

Therefore, in this article, it is tried to collect the new conception about the emotion and its location in the human person and show the way to link it to the education, to the values formation with the cinema, that can arrive directly to the emotional sight of the person so-called to be received from the whole of the person and well-spent like a message, an educational and cultural communication.

Key words: education, emotion, emotional teaching literacy, education in values, pedagogic intervention, film language. 


\section{SOMMAIRE}

Souvent, l'éducation et surtout la formation au sein des institutions éducatives a été identifiée à une vision de la personne où la raison s'est convertie en critère et contrôle d'absolument tout. Et c'est pour celà que l'on n'a prétendu que travailler avec les connaissances pour une intelligence séparée de tout ce qui transforme une personne en humaine, en être vivant qui sent, se réjouit, souffre.

En ce sens, le sujet émotionnel a été (ou est) sous-estimé pour ne pas dire non abordé tant il est suspect ou redoutable. (Peut-être aussi à cause de cette repression se sont produites des explosions brutales au niveau émotionnel et passionnel). Cependant, la personne est un être appelé à intégrer ses dimensions cognitives, émotionnelles et volitives. De prestigieux psychologues contemporains ont démontré cette integration dans leurs études sur l'intelligence émotionnelle.

C'est pourquoi, dans cet article, il s'agirait de recueillir les nouvelles conceptions sur l'émotion et son lieu au sein même de l'être humain et de présenter une façon de la lier à l'éducation, à la formation de valeurs à travers un moyen, le cinéma, qui parvient directement à la partie émotive de la personne mais qui est amené à être reçu par la totalité de la personne et exploité comme un message, une communication d'éducation et de culture.

Mots clef: éducation, émotion, alphabétisation émotionnell, éducation en valeurs, intervention pédagogique, langage cinématographique.

La esencia de mi opinión actual es que los sentimientos son la expresión de la prosperidad o de la aflicción humana, tal como ocurren en la mente y en el cuerpo. Antonio Damasio $(2005,13)$.

\section{INTRODUCCIÓN}

Cuenta Plutarco que, en tiempos del emperador Augusto, unos marineros oyeron en las aguas del Mediterráneo unas voces que afirmaban: "Que todo el mundo lo sepa: el gran dios Pan ha muerto, ha muerto, ha muerto".

Hay quien interpreta en esta leyenda el anuncio de una nueva época, la de la transición de la cultura rural agrícola encerrada en sí misma a una nueva cultura más universal, y que era necesaria implantar en todo el orbe del imperio romano.

Por otra parte sabemos que Höderlin exclama aquello de, "y, ipara qué dioses en tiempos de zozobra!». El siglo XX ha sido el siglo de la consolidación del cine como medio de expresión cultural. Un nuevo dios. La imagen daba la impresión de que iba a arrinconar a la palabra escrita. En este siglo ya se vislumbra un tiempo global en donde el mundo de la comunicación se apoya en los últimos avances tecnológicos, como el "sms" que usa y transmite desde la palabra a las imágenes consiguiendo un lenguaje integrado. Esta situación permite que algunos lenguajes puedan dedicarse más íntimamente a llenar el ánimo del espectador, es decir el ánima, lo más íntimo, ese hálito en donde el ser humano se encuentra con su propia mismidad. Él 
es en sí mismo y para ello usa un lenguaje ya consolidado, el cine, en donde la palabra escrita, el guión, se traduce en imágenes que le producen una serie de emociones que lo hacen ser más él.

El arte cinematográfico es tal sólo cuando enraizado en lo más inmediato se transciende, se enjuaga en el tiempo y se empapa de vida dando lugar a una historia que eclosiona en un torrente de emociones.

Conscientes, por lo tanto, de que la imagen es para nuestra época una revolución más intensa aún de la que historiaba Plutarco y convencidos de su poder y omnipresencia, especialmente en la infancia y juventud, queremos incidir en las posibilidades que ofrece el cine a la hora de afrontar la educación de las emociones, una tarea absolutamente necesaria en la actualidad. La fuerza del cine para proyectarse en el corazón de las personas con toda su riqueza comunicativa nos invita a servirnos de él como un recurso pedagógico, posiblemente el más completo y mejor, para la alfabetización emocional del educador y del educando ${ }^{1}$.

\section{APROXIMACIÓN AL CONCEPTO DE EMOCIÓN}

Consideramos que es obligado trazar un esbozo que abarque conceptos con los que se relaciona la emoción, características del campo afectivo y parámetros del estado afectivo.

Si queremos analizar las funciones afectivo-emotivas, deberemos atender, desde el punto de vista de la investigación, a un alto grado de "anarquía científica" porque dentro de las mismas se incluyen: el sentimiento, la emoción, el estado de ánimo o humor, la pasión y la motivación. Se requiere aún cierta organización y precisión.

Estas experiencias del afecto son las que, concretamente, nos confirman la diversidad y complejidad del contenido del campo objeto de estudio.

Las distinciones que se realizan poseen un carácter superficial, puesto que entre ellas no existe una clara separación y se encuentran imbricadas unas con otras haciendo que se difuminen sus particularidades y se torne borrosa su diferenciación. Se parte de una continuidad en los estados afectivos que imposibilita su rigurosa clasificación, debido a que la afectividad no sigue una línea ordenada y clara. Esto significa que podemos afirmar que no hay estados afectivos puros, es decir, habrá que clarificar cada elemento (emoción, pasión, sentimiento, estado de ánimo, etc.) para definir el "estado afectivo" adecuadamente, lo que prueba que es

1. Como prueba de ello traemos a colación el pensamiento de este director de cine: «Pienso que la influencia del arte está en los individuos y el efecto resultante está en la sociedad. Éste ejerce su influencia cambiando la mirada del observador. Y cuando la mirada de alguien hacia la vida cambia, su comportamiento cambia. Pienso que la humanidad puede, aún ahora, avanzar mediante el cine, decirle a la gente que no sea egoísta y que comparta la vida con otros" (MOHSEN MaKhmalbaF). www.pulmovies.org/articulos/real_subjetivo.html. (Página consultada, 14 de mayo de 2006). 
condición necesaria que éste sea un conglomerado de los mismos. Un elemento común a todos los conceptos es que encierran las claves para profundizar en la afectividad ${ }^{2}$.

A fin de tener un marco de referencia, transcribamos la definición de la Real Academia Española sobre emoción: "Alteración de ánimo intensa y pasajera, agradable o penosa, que va acompañada de cierta conmoción somátican.

La evolución histórica de las emociones evidencia un cambio sustancial que va desde una visión negativa de éstas, como perturbadoras de la razón y distorsionadoras de la conducta (concepción adoptada durante el siglo XIX y gran parte del XX), a una visión positiva de las mismas, realzando su función en el bienestar y desarrollo personal, así como su papel decisivo en la adaptación positiva de todo ser humano. Esta importancia está sin duda determinada por su indiscutible efecto benefactor sobre la salud y la calidad de vida de las personas.

Distintos marcos teóricos sobre la emoción proliferaron a lo largo de la historia. Esta situación motiva la existencia de diferentes enfoques: evolucionistas-biológicos, psicofisiológicos, neurológicos, psicoanalistas, conductistas, cognitivos, etc. Evidentemente sobre las emociones se han escrito numerosas y variadas teorías, habiendo consenso general en algunos aspectos, que en absoluto proyectan unanimidad, como bien afirma Rojas "todos sabemos de ella, pero cuando intentamos atraparla conceptualmente nos damos cuenta de su complejidad" $(1998,12)$. Esta situación nos parece fundamental a la hora de entender la simbiosis existente entre la emoción y el cine porque las experiencias emocionales y audiovisuales son

2. La mayoría de los autores entienden que la acepción afectiva del vocablo sentimiento se centra exclusivamente en el propio acto de la experiencia sensorial. Por lo tanto, es un estado subjetivo, difuso, suave y duradero que directamente se relaciona con el pensamiento y la imaginación.

Es, en definitiva, un estado afectivo bipolar - positivo o negativo- matizado por variables culturales, sociales y biográficas que están influyendo directamente en la manifestación de la conducta o del comportamiento del sujeto.

Los términos más usados que definen la emoción son: agitación, reacción, conmoción áspera y súbita, elevada activación, brevedad, alteración, intensidad y fugacidad. Según estas caracterizaciones, los estados emocionales suponen su identificación como afectos bruscos desencadenados por una percepción imaginaria o simbólica produciendo un desequilibrio somático - vegetativo, glandular, muscular...- y psíquico que moviliza los mecanismos adaptativos del individuo frente al desencadenante.

El estado de ánimo o bumor es un tipo de afecto de identificación lenta, progresiva y cíclica reconocido como un estado vital permanente, uniforme, vago y constitutivo de una respuesta o reacción transitoria en un individuo concreto.

La pasión se presenta como cualquier perturbación intensa y permanente del afecto desordenado del ánimo. Actualmente, la psicología contemporánea entiende la pasión como una experiencia vivida que polariza la afectividad hacia acciones exteriores de los demás, invadiendo toda la vida psíquica del sujeto y haciendo una reorganización de su vida consciente, o lo que es lo mismo, el equilibrio entre la mente racional y emocional se rompe haciendo que la "mente que siente" se desborde y secuestre a la "mente que piensa" para ejercer su control. En resumen, podemos decir que el factor afectivo es la particularidad más dominante de la pasión (VÁzQuez Gómez, 1984; GuTtírRez MoAr, 2004). 
decisivas en la construcción de la identidad personal y en las posibilidades que se establecen en la educación para la vida, para la felicidad y para el bienestar.

Así mismo conviene aceptar que las emociones van siempre acompañadas de reacciones somáticas: alteraciones en la circulación, cambios respiratorios o secreciones glandulares. A su vez las emociones tienen características significativas como una dimensión social, que se manifiestan corporalmente y que son las que le dan esta peculiaridad. Así sentiremos cólera, temor, miedo, gozo, alegría, risa, angustia, compasión, amor... Añadamos que los estados emocionales de las personas dependen tanto de la actividad fisiológica como de la situación cognitiva del sujeto ante lo que ve, oye, siente, observa, palpa, etc.

Por su parte las emociones proyectan o generan estados psicológicos cuando se producen interferencias a favor o en contra del proceso emocional. Éstas, por lo general, no son fáciles de controlar, aunque las manifestaciones externas de las mismas sean más evidentes y controlables.

A finales del siglo XX se difundieron los resultados de investigaciones que comprobaron la unidad del ser humano. En este sentido vincularon la emoción con inteligencia y así han llegado a conclusiones de gran interés. Entre ellas, resaltamos las de Salovey y Mayer (1990), Goleman (1996, 1998, 2003), Gadner (2001, 2004, 2004a) y Damasio (2005).

Desde que en la década de los años de 1990 los profesores Salovey, de la Universidad de Yale, y Mayer, de la Universidad de New Hampshire, ambas en Estados Unidos, acuñaran por primera vez el término «inteligencia emocional"(IE), hemos asistido a una "revolución emocional", incrementada cuando Goleman, de la Universidad de Harvard, difundió este constructo. Este autor se encargó de destacar el poder que tienen las emociones en el desarrollo personal y social de los individuos en lo que se refiere a la "salud emocional", la educación y el mundo empresarial. Hoy día la relación entre inteligencia y emoción ha merecido que ésta cobre la relevancia social otorgada. Ya no es algo solamente personal y que se debe dominar y ocultar, sobre todo en los ámbitos profesionales y sociales, sino que se valora su influencia en la formación de la persona y en su capacitación para el desempeño de determinadas tareas que requieren o mejoran cuando se las concibe y ejecuta no sólo con "inteligencia", sino con "inteligencia emocional". El equilibrio personal y las habilidades sociales son cada vez más demandadas para desempeñar cualquier tarea social o laboral.

Otro autor de relevancia, Gardner (2001), se encargó de proponer y defender la teoría de las inteligencias múltiples (IM) ${ }^{3}$, según la cual se reconoce que la inteligencia no es única y unidimensional, sino que, por el contrario, existen distintas

3. El propio GARDNER (2001) reconoció su interés por examinar la cognición humana desde la perspectiva de distintas disciplinas: psicología, neurología, biología, sociología, antropología además de las artes y las humanidades. 
clases de inteligencias pluridimensionales ${ }^{4}$. El ser humano tiene la totalidad de las inteligencias, cada una con un desenvolvimiento propio y distinto, donde intervienen la dotación biológica, su interacción con el mundo y los otros y la valoración cultural asociada a su experiencia personal. La definición de inteligencia que aporta Gardner (2001, 2004, 2004a) se basa en reconocerla como un potencial bio-psicológico para la resolución de problemas y para crear productos que sean valiosos en uno o más ambientes culturales. Estas inteligencias se combinan, entrecruzan y se usan desde diversas formas e intensidades de tal modo que cada individuo difiere de los demás en el grado en que las manifiesta. Entre ellas están las llamadas inteligencias personales que están referidas a las emociones tanto intrapersonales ${ }^{5}$ como interpersonales ${ }^{6}$.

Aquí damos entrada al beneficio potencial de este artículo, que estriba en un cambio de tendencia que nos permite pasar de un olvido tradicional de las emociones en los contextos educativos a darles un énfasis especial cuando éstas se vinculan a la cultura de la imagen a través del cine.

Uno de los máximos exponentes del estudio de las emociones, Damasio ${ }^{7}$, matiza al respecto: “El cerebro utiliza varias regiones específicas que trabajan en concierto para representar una mirada de aspectos de las actividades del cuerpo en forma de mapas neurales" $(2005,13)$.

Igualmente, Francisco J. Rubia afirma que las emociones: “Son una respuesta evaluadora del organismo que supone una combinación de alerta fisiológica, que incluye la activación del sistema nervioso autónomo o vegetativo, una experiencia subjetiva, como amor, odio, ira, etc., y una expresión conductual o emocional, como las expresiones faciales que indican una emoción determinada" (2006, 24).

Por lo que venimos expresando, a lo largo de estas líneas, desde los planteamientos de la educación emocional (Bisquerra, 2003), como forma de prevención primaria inespecífica ${ }^{8}$, trataremos de demostrar la necesidad de la alfabetización audiovisual y emocional de los sujetos centrándonos especialmente en la importancia de que el cine se dirija al corazón como un recurso para la intervención pedagógica que nos ayude a la alfabetización emocional del educador y del educando (Aguilló, 2000; Ferrés, 2003; Couce y otros, 2004; Martínez López, 2005). Sólo en la medida en que los individuos sean capaces de tomar conciencia de las

4. En la teoría de las inteligencias múltiples (IM) de Gardner inicialmente se perfilaron siete clases de inteligencias: musical, cinética-corporal, lógico-matemática, lingǘstica o verbal, espacial, interpersonal e intrapersonal, y posteriormente este mismo autor incluyó la octava denominada inteligencia naturalista.

5. Capacidades para resolver problemas referidos a nuestras emociones.

6. Capacidades para resolver problemas referidos a las emociones de los demás.

7. Reciente Premio Príncipe de Asturias de Investigación Científica y Técnica, 2005.

8. Pretende minimizar la vulnerabilidad de las personas a través del fomento de competencias básicas para la vida (actitudes positivas, control emocional, capacidad para decidir, etc.). 
emociones que experimentan a través del cine, o de cualquier mass media, podrá llegar a captar el verdadero mensaje que los medios le proponen.

Así, esta revolución emocional ha conseguido que se hayan generado cambios en el entendimiento de los diferentes ámbitos de la realidad y de las ciencias. Las ciencias empresariales, la pedagogía y la psicología han coincidido en la necesidad de establecer modificaciones buscando aplicaciones prácticas de los planteamientos que venimos reseñando.

Hay que aceptar que a pesar del escaso conocimiento que se posee todavía sobre los procesos y la inteligencia emocional con relación a las actividades ubicadas en la corteza superior del cerebro, sería aberrante afirmar que se puede vivir sin la presencia de las emociones o ir en contra de ellas.

Quizás por un desconocimiento de la realidad y, consecuentemente, la ausencia de un tratamiento objetivo, desde siempre la educación ha desempeñado el papel de racionalizar, de controlar las emociones. De aquí esos argumentos, que van mucho más allá del error, de haber singularizado las emociones como el componente irracional y detestable del ser humano. Por consiguiente su necesidad de educarlas y controlarlas. En la cultura occidental ha habido períodos y tendencias diversos y en ellos ha influido un conocimiento sin apoyo en la realidad y sin base objetiva.

La importancia concedida a las emociones en el último cuarto del siglo pasado ha llevado a revisar el concepto de inteligencia, y en ella se han incluido y reconocido elementos emocionales, surgiendo el término de "Inteligencia Emocional" (Goleman, 1996) al que nos acabamos de referir. Estaría compuesta precisamente por una serie de habilidades emocionales, definidas como aquellas capacidades y acciones que asientan conscientemente un estado de ánimo o sentimiento a partir de las ideas que tenemos sobre lo que acontece (Vallés y Vallés, 2003). Por tanto, es la inteligencia la que se asocia con la propia conciencia y armonía de uno mismo y la de los otros, con el equilibrio entre expectativas y logros (De la Torre, 1999, 2000).

En el avance de la teoría de las emociones, hoy se acepta la existencia de una inteligencia emocional a la que ya hemos aludido pero de la que quisiéramos añadir algo más dada la resonancia que en algunos ámbitos ha adquirido. En su papel de propagador de estas ideas, Goleman (2003) expresa que la inteligencia emocional es el conjunto de habilidades que sirven para expresar y controlar los sentimientos de la forma más adecuada para desenvolverse en el terreno personal y social. La emoción es una respuesta compleja, rápida y corta que implica actividad fisiológica, psicológica y conductual, que dispone a la acción y ayuda a las personas a solucionar problemas, situaciones complicadas y decisiones asociadas a la vida y la supervivencia. En un sentido coincidente, encontramos las afirmaciones de Rojas sobre las emociones que están determinadas como conducta, "por las circunstancias externas, personales y biográficas" (1998, 37).

En cuanto a los tipos de emociones no se aprecia una clasificación cerrada de las mismas, puesto que existen centenares de emociones y a su vez se encuentran entrelazadas. Una clasificación podría ser la que diferencia entre emociones positivas 
(alegría, amor, agradecimiento, etc.) y emociones negativas (miedo, tristeza, ira, etc.). Del mismo modo Goleman (1996) señala que debemos considerar las emociones en términos de dimensiones, destacando como emociones primarias la ira, la tristeza, el miedo, la alegría, el amor o la vergüenza, y el resto de las emociones como variantes o mezclas de las anteriores. Por su parte, Bisquerra (2000) distingue entre cuatro clases de emociones: emociones negativas (ira, miedo, tristeza, vergüenza, etc.); emociones positivas (alegría, amor, etc.); emociones ambiguas (sorpresa, esperanza, compasión, etc.); y emociones estéticas, vinculadas a la admiración y al placer artístico.

Se comprende, por lo tanto, que la familia, la escuela y demás agentes educativos sociales deben promover la alfabetización emocional, es decir, el desarrollo o cultivo de la inteligencia, ya que destacados y variados estudios han demostrado que el éxito en la vida no depende únicamente del cociente intelectual, entendido en sentido clásico, sino sobre todo de la inteligencia emocional de la persona (Vaillant, 1997; Herrnstein y Murray, 1994). Desde esta perspectiva muchos de los programas de alfabetización emocional aplicados en los centros escolares consideran el trabajo y la participación de las familias, de manera que padres y madres refuercen lo aprendido por sus hijos en la escuela y contribuyan a su desarrollo emocional.

Coincidiendo con Goleman (1996) esta alfabetización emocional o potenciación de la inteligencia emocional debe atender a los siguientes aspectos:

- Saber identificar las propias emociones y su adecuada interpretación.

- Conocer las vías necesarias para controlar nuestras diversas emociones y asumir las decisiones y conductas.

- Comprender la empatía, como la capacidad que facilita el conocimiento de los demás poniéndose en el lugar del otro.

- Desarrollar habilidades sociales que favorezcan la comunicación, la clarificación y la resolución de conflictos.

Si establecemos un balance, estimamos que el estudio del mundo emocionalafectivo requiere una postura ecléctica, porque una emoción no se puede reducir a un solo plano de los presentados, sino que todos ellos se entrelazan para matizar un análisis correcto. Por ello, ofrecemos el siguiente cuadro sobre una posible ordenación de las emociones: 
CUADRO 1. UNA CLASIFICACIÓN EMOCIONAL ADECUADA A NUESTROS PROPÓSITOS

\begin{tabular}{|c|c|c|c|c|c|c|c|}
\hline IRA & TRISTEZA & TEMOR & PLACER & AMOR & SORPRESA & DISGUSTO & VERGÜENZA \\
\hline Furia & Congoja & Ansiedad & Felicidad & Aceptación & Conmoción & Desdén & Culpabilidad \\
\hline Ultraje & Pesar & Apresión & Alegría & Simpatía & Asombro & Desprecio & Molestia \\
\hline Resentimiento & Melancolia & Nerviosismo & Alivio & Confianza & Desconcierto & Menosprecio & Disgusto \\
\hline Cólera & Pesimismo & Preocupación & Contento & Amabilidad & & Aborrecimiento & Remordimiento \\
\hline Exasperación & Pena & Consternación & Dicha & Afinidad & & Aversión & Humillación \\
\hline Indignación & Autocompasión & Inquietud & Deleite & Devoción & & Disgusto & Arrepentimiento \\
\hline Aflicción & Soledad & Cautela & Diversión & Adoración & & Repulsión & Mortificación \\
\hline Acritud & Abatimiento & Incertidumbre & Orgullo & Infatuación & & & Contrición \\
\hline Animosidad & Desesperación & Pavor & Placer sensual & Ágape & & & \\
\hline Fastidio & Depresión & Miedo & Estremecimiento & & & & \\
\hline Irritabilidad & & Terror & Embeleso & & & & \\
\hline Hostilidad & & Fobial & Gratificación & & & & \\
\hline Violencia & & Pánico & Satisfacción & & & & \\
\hline Odio & & & Euforia & & & & \\
\hline & & & Extravagancia & & & & \\
\hline & & & Éxtasis & & & & \\
\hline & & & Manía & & & & \\
\hline
\end{tabular}

Fuente: Elaboración propia adaptada de GolEman, 1998.

Esta clasificación de las emociones nos servirá para enlazar y entender el sentido a nuestro estudio sobre cine y emociones, ya que el cine constituye un poderoso recurso pedagógico que puede ser utilizado por las familias y docentes y para valorar todas sus posibilidades educativas que éste ofrece, especialmente, en la alfabetización o educación emocional.

Aceptando además que "tal vez el ámbito de la vida humana en el que la imperfección se advierte más acusadamente, en el que la necesidad de ayuda y reparación es más acuciante, en el que la conciencia muestra los límites más a la vista y a flor de piel, en el que la cultura puede aportar a la vida mayor calidad, puede que sea el campo de las emociones y los sentimientos; siendo éstos uno de los recursos más importantes y maravillosos de que disponemos para andar por la vida" (García Carrasco, Canal, Bernal y Martín, 2006, 33).

\section{EL VALOR DEL CINE EN LA EDUCACIÓN}

Desde lo absurdo que es concebir al ser humano como un ser dual donde se separe la dimensión afectivo-emocional y la racional nos permitimos entender que es básico para configurar la identidad de las personas. Desde esta consideración, el tema de la emocionalidad, el afecto y la empatía ha de reconocerse y defenderse junto a la evolución de la mente. La clave está en mantener que lo que conocemos de las emociones, como afirman Asensio, Acarín y Romero, "no desvalorice nuestra singular racionalidad o que reste importancia a las influencias del medio 
socioeducativo para moldear el comportamiento, sino que este conocimiento nos permite integrar lo afectivo y lo racional en un juego de mutuas influencias" (2006, 19). En este sentido, el cine como instrumento pedagógico que se adentra, reproduce e investiga la vida humana, sus conflictos, pasiones y emociones nos conecta con el "como si", es decir, ese mundo irreal o percepción virtual desde la cual vivimos y sentimos, reconociéndonos, identificándonos, transformándonos y adaptándonos a través de la risa, la tristeza, el amor, el gozo... despertando en el espectador unos sentimientos, pensamientos, actitudes que transferirá al aprendizaje de experiencias en un medio y situación concreta.

Y para cumplir esta función miramos al mundo que nos circunda y es indudable que vivimos en una realidad donde lo audiovisual empapa todo nuestro entorno y esto se evidencia con más intensidad en la etapa infantil donde a menudo conectan con el mundo a través de su representación audiovisual. Estas circunstancias, que en muchos momentos han sido catalogadas como un problema para la educación, estamos seguros de que nos dan opción a educar y a aprender en escenarios donde convergen muchos más sentidos. Ya no sólo impera la acción repetitiva, sumativa y memorística, sino aquella que combina la imagen, los planos, el encuadre, la acción, la luz, la música, los efectos sonoros, la palabra... dentro de un contexto integrador apoyándose en el movimiento de las 24 imágenes por segundo que ofrece inmensas posibilidades además de utilizar la imagen fija como elemento clave de la atención.

La nueva información, sustentada más en la imagen que en la palabra, ha cambiado la jerarquía de los sentidos pues la visión natural prevalece sobre la alfabética, ha aumentado el valor de la imagen - y con ella la supremacía de lo menos estructurado sobre lo más estructurado-, ha modificado la naturaleza de la escritura y la tipología de los textos, que son ilimitadamente modificables, y, por último, ha originado una nueva forma de elaborar la información no proposicional, es decir, la elaboración ha pasado de ser analítica, estructurada, contextualizada y referencial a ser indiferenciada.

Durante siglos el ser humano ha luchado por capturar la realidad en una imagen. Por ejemplo, existen especialistas que afirman que las pinturas rupestres de Altamira no tenían otra intención que capturar el alma rápida del animal y al inmovilizarlo en una imagen se adquiría dominio sobre él, se hacía menos veloz y su caza resultaba más fácil. Representan fotogramas instantáneos de un deseo de inmovilizar al animal para atraparlo.

Durante siglos el ser humano ha deseado capturar, captar la realidad móvil para poseerla, vivirla tal cual la percibía pero ésta, cuando los más hábiles hombres la convertían en una obra de arte, se transformaba en algo estático. Así sucedía con la escultura y la pintura a pesar de su gran perfección.

La fotografía de mediados del siglo XIX significó un avance y a pesar de que no se consiguió el movimiento se obtenía la realidad tal como era y, aunque no cautivó a las masas, fue perfilándose y logrando nuevos efectos a través de la sucesión de planos. Algo similar podemos decir de las secuencias de un film en donde 
se proyectan las vidas, que quienes las ven, sienten que las viven, padecen, sufren, lloran o ríen con ellas.

Conviene no olvidar que el cine, en sus inicios y a modo de motivación primaria, nació como una experiencia de física recreativa (Hueso, 1998; Gubern, 2005, 77). Cuando verdaderamente surgió el cine, la fotografía en movimiento, fue capaz de emocionar a quien lo veía. Apareció un nuevo arte en el instante en el que el cineasta logró editar planos, resaltar con la cámara detalles y momentos de forma que intensificaban la emoción del relato. Estábamos ya en algo diferente y más complejo que el teatro.

Hay quien ha señalado que el gran atractivo que ejercía sobre Griffith la belleza de una actriz le motivó a filmarla con diferentes planos y editarla para hacerla suya, viéndola y recreándose en los aspectos más concretos que le emocionaban. Es decir, que de la interrelación de la imagen filmada por el director y la editada por otra persona nació el cine como arte, en un diálogo creador de imágenes que expresaban los sentimientos que el director deseaba, el guión señalaba y el editor secuenciaba otorgando unidad y sentido a la obra de arte que lo único que perseguía, como producto final, era emocionar. Pero si solamente la imagen ya emocionaba faltaba la palabra. Y una obra de arte sin palabra, sin música no era perfecta, por tanto, el cine sonoro completó rotundamente el esquema y nació, definitivamente, el séptimo arte.

De esta forma el cine fue adoptando una trayectoria propia. La pintura necesitó hacerse abstracta para poder competir, o surrealista para elevar al máximo la imaginación. El teatro pareció que perdía fuerza frente al cine. Sólo la novela se mantenía firme. El cine no tuvo más remedio que tomar de la novela la narración, y los planos se personalizaron con el diálogo y las escenas y las emociones se desbordaron como un torrente sobre los espectadores. Valgan las siguientes muestras donde cine y literatura se funden dando origen a nuevas obras de arte, Lo que el viento se llevó (Victor Fleming, 1939), 2001 Una odisea del espacio (Stanley Kubrick, 1968), Los santos inocentes (Camus, 1984), En nombre de la rosa (Jean-Jacques Annaud, 1986), El perro del Hortelano (Pilar Miró, 1995) o Charlie y la fábrica de chocolate (Tim Burton, 2005), por citar algunas.

El cine es además una ventana abierta al mundo que ofrece un lenguaje, un medio de comunicación, un arte... donde se conjuga un análisis técnico, estético, sociológico, psicológico y pedagógico de la realidad que nos ha tocado sentir y vivir (Bautista y San José, 2002; Tarkovski, 2002; Ortigosa, 2002; Martínez-Salanova, 2003; Eco, 2004).

Las emociones se expresan mediante movimientos corporales, gestos, mímica, sonidos... dando lugar a una gran elaboración artística de lo emocional desde la música, la literatura, las artes plásticas, el teatro y el cine. Se identifican como los lenguajes de las emociones y sentimientos que conllevan una base sociocultural y que, por lo tanto, pueden ser enseñados y aprendidos.

Por consiguiente, la finalidad del binomio "cine y emociones" no es otra que la de garantizar un proceso de educación integral caracterizado por un adecuado 
grado de homeostasis entre las dimensiones personales y sociales de los individuos, es decir, el sentido de globalidad del ser humano.

Ajustándonos al marco teórico de partida sobre cómo evoluciona el conocimiento de la educación y la sistemática de las disciplinas, pasamos a identificar cuál es el papel que ocupa el cine y cómo se vincula a la pedagogía afectivo-emocional.

Desde la disciplina académico-sustantiva de la pedagogía identificada como pedagogía afectivo-emocional nos proponemos dar respuestas a cuestiones teóricas y tecnológicas específicas del sector educativo que estudian autónomamente la dimensión emocional del ser humano con la finalidad de realizar adecuados procesos de intervención pedagógica (Touriñán, 1987) ${ }^{9}$. Dentro de este objetivo el cine se identifica como un recurso idóneo encargado de canalizar la alfabetización emocional del individuo.

Se debe establecer la diferencia entre una pedagogía con los medios que puede entenderse como aquellas acciones educativas que utilizan los medios de comunicación. Así como las nuevas tecnologías de la sociedad de la información en apoyo de la enseñanza son recursos a una pedagogía de los medios, en este caso los audiovisuales, el cine, la televisión, los mass media, Internet, son el objeto de estudio y de aprendizaje. Es preciso aprender el lenguaje propio de la imagen cuando se utiliza en un contexto o en otro, los medios de que se disponen, así como la interacción con las redes informáticas ya que, en el fondo, trasciende una ideología.

Desde esta consideración entramos en la necesidad de vincular la importancia de la cinematografía y la competencia emocional porque sólo así podremos entender y comprender qué significado tiene la experiencia de ser espectador frente a los fenómenos que se sitúan entre la razón y las emociones dentro de la identidad sociopersonal de los individuos.

Desde un punto de vista psicopedagógico, el cine se convierte en una vía de proyección, ya que una vez vista la película el receptor vivencia los contenidos emocionales a través de los actores y/o transfiere sus sentimientos y conflictos hacia dichos personajes. Por este motivo entramos en la relación causa-efecto (dimensión racional) y en estructuras de asociación y transferencia (dimensión emocional) del uso de los medios audiovisuales.

Podemos coincidir parcialmente con algunos autores que señalan cómo las nuevas generaciones están sumidas en un mundo absolutamente caótico, que nadan en un magma informe de imágenes equivalentes que incrementa su emotividad, que empobrece y descontextualiza las estructuras explicativas, cuando lo que necesitarían sería potenciar su concentración, su atención, su capacidad de espera, su percepción ilativa, encadenada y abstracta, no meramente impresionista,

9. En resumen, desde los planteamientos científicos defendidos por Touriñán (1987, 260) determinamos que «todo conocimiento teórico o tecnológico de la ciencia de la educación es conocimiento que crea intervención pedagógica". 
imaginativa (de imagen), y emotiva (Aguilar, 1996, 51; Rodríguez Neira, 1999, 5051; Núñez, 2000; Esteve, 2003; Touriñán, 2004).

Nos encontramos ante la mediocridad de un nuevo analfabetismo. El hombre light, la persona "Suave" no tiene el mínimo interés por lo cultural, su máxima definitoria es la superficialidad y tiende a huir de cualquier intento de entrar a conversar sobre temas culturales, desarrollando y recurriendo de inmediato a una trivialización de éstos.

Constatemos cómo Sartori denuncia directamente a los agentes responsables de esta ceguera teledirigida: familias, educadores, centros educativos, periodistas, medios de comunicación, formadores de periodistas y empresas de comunicación, principalmente. Esto obliga al profesorado hacia una responsabilidad para advertir de la importancia destructora de la imagen si no se la considera:

Para encontrar soluciones hay que empezar siempre por la toma de conciencia. Los padres, aunque como padres ya no son gran cosa, se tendrían que asustar de lo que sucederá a sus hijos: cada vez más almas perdidas, desorientados, anómicos, aburridos, en psicoanálisis, con crisis depresivas y, en definitiva, enfermos de vacío. Y debemos reaccionar con la escuela y en la escuela. La costumbre consiste en llenar las aulas de televisores y procesadores. Y deberíamos en cambio vetarlos... (1998, 154).

No está de más aprovechar las ideas de este autor para recalcar la necesidad de la educación audiovisual ya que no es lo audiovisual algo que se debe absorber acríticamente (como si fuera algo natural, neutro, inocuo) sino que es prudente enfrentarse activamente a sus influencias y mensajes de una forma menos espontánea a como lo hacemos con los textos escritos.

Interesa desarrollar un nuevo escenario creativo en el que, a partir de un sistema comunicacional dialógico, el alumnado sea capaz de interaccionar de una forma horizontal, donde la participación sea democrática e igualitaria ya que todos ven el film y todos pueden reflexionar y participar. Por consiguiente, habrá que atender si es necesario hacer realidad la siguiente afirmación de Sartori:

Pero los que todavía son pensantes tienen que denunciar la irresponsabilidad e inconsciencia de las cada vez mayores legiones de vendedores de humo que olvidan que la ciudad en la que vivimos y viviremos no es "naturaleza" (una cosa dada que está ahí para siempre), sino que es de cabo a rabo un producto artificial construido por el homo sapiens $(1998,197)$.

A partir de esa doble forma de entender que ha hecho imprescindible la superposición de la cultura audiovisual presentada tradicionalmente como la única y que ha reclamado este autor en acertada expresión: entender mediante conceptos y entender a través de la vista han de combinarse en una suma positiva, reforzándose o al menos integrándose el uno en el otro. Así pues nos sumaríamos a la tesis de este estudioso de acuerdo con la cual la persona que lee y la persona que ve, 
la cultura escrita y la cultura audiovisual, están destinadas a sumarse en una síntesis armoniosa.

De igual forma a como acontece con el lenguaje escrito, se produce una relación entre el receptor-espectador, el emisor-director y texto-mensaje audiovisual. Recibir un mensaje audiovisual implica comprender, descifrar, interpretar lo que alguien ha expresado. Ahora bien, la riqueza y la calidad de la recepción de ese mensaje dependerán no sólo de la intención del emisor y de las características del mensaje sino también de la capacidad y formación para la lectura audiovisual del receptor-espectador.

En el caso del cine resaltamos además su carácter global, la pluralidad de dimensiones que contiene. Así, conjuga el lenguaje verbal y no verbal, constituyendo un medio de expresión total; es una verdadera obra de arte, ya que se alberga una demostración creadora y comunicativa; es un instrumento de transmisión de conocimiento, dado que oferta diversidad de capacidades informativas. De ahí que para nosotros la enseñanza con, por y desde el cine representa una exigencia social. Y no sólo para la formación de la persona, sino porque además el cine también es una alternativa de ocio y recreación personal.

Y recordemos que la comunicación en el cine se produce a tres niveles. El primer nivel sería el de los sistemas perceptivos, vista y oído, de forma que se puede acceder a la información de un modo inmediato, únicamente a través de los estímulos más primarios. En un segundo nivel, estarían los lenguajes asociados a los sistemas perceptivos: imagen, sonido fonético y musical, ruidos y señales. Todos ellos producen una amplia gama de referentes culturales de reconocimiento y codificación. Y el tercer nivel sería el que actúa de forma subconsciente. La disposición de los encuadres y utilización de la luz, los movimientos de cámara, la elección del espacio escénico, el manejo de la música y el movimiento de los actores, entre otros, son elementos que el espectador medio no percibe conscientemente, pero son los que combinados logran que las películas nos transmitan determinadas sensaciones y emociones. Estos tres niveles se han organizado de forma estudiada y refinada para que los mensajes cinematográficos adquieran una compleja red de comunicación. Por eso hay que reconocer que el sistema del lenguaje cinematográfico es una de las conjunciones más impresionantes que existen desde el punto de vista de la comunicación humana. Consecuentemente, la información que codificamos gracias a las películas es capaz de provocar cambios, emociones y llegar de un modo claro y diáfano a todos los sectores de la población. Es indudable que la técnica juega en el cine un papel determinante y, aunque pueda producir el efecto contrario, en una película todo ha sido planificado cuidadosamente (Pereira y Urpí, 2005).

Quisiéramos detenernos brevemente en el valor comunicativo del cine. En este sentido hemos de destacar que toda la importancia de la técnica ha de estar puesta en función del espectador. Ha de sentirse implicado, ver reflejada su visión de la realidad, sus intereses, sus deseos en lo que sucede en la pantalla, es decir, ha de producirse su participación afectiva y su reconocimiento en el mundo que presenta la película (Dios, 2001, 2005). 
También aludiremos al proceso de identificación-transferencia que tiene lugar en el cine. Curiosamente, a pesar de que no nos reconozcamos todos plenamente en unos actores y a pesar de que todos queramos mantener una cierta imagen de nosotros mismos independiente de ellos, no cabe duda de que este fenómeno se produce. Hay un momento en el que tiene lugar una transferencia mágica, un desplazamiento secreto de una personalidad a la otra.

Cuantos han estudiado el carácter de la comunicación cinematográfica han tenido que resaltar su capacidad para potenciar los sueños, los temores, las esperanzas de cada uno de los espectadores. Sus formas concretas, absolutamente reales, que el espectador relaciona con su mundo cotidiano, no le impiden avivar la imaginación y fomentar una sensación de libertad, de liberación de una vida en ocasiones triste y anodina. Se reconoce con los protagonistas del film más allá de la pantalla y termina por identificarse con las estrellas cinematográficas y compartir sus problemas y hasta su vida tal como los perciben a través de los medios de comunicación ${ }^{10}$.

Igualmente, subrayamos la inmensa capacidad del cine para transmitir un conocimiento directo, vivo, real de acontecimientos y sucesos sociales. El cine no sólo llega a la inteligencia de las personas, sino también conecta con sus emociones, para generar motivaciones y para facilitar el compromiso de las personas con el cambio. Cambio que se puede producir o favorecer a partir de la realidad más inmediata y es que el mundo de hoy no le es ajeno en absoluto al mirar una pantalla, incluso podría decirse que ésta forma parte del mundo de hoy y se conforma en un objeto de uso diario (González Blasco y otros, 2006, 345-402). Todo nuestro entorno podría decirse que es una inmensa y variada pantalla. Miramos la pantalla del cajero automático para sacar dinero, miramos la pantalla de cine, la gran pantalla de un concierto en directo, la esfera del reloj, la pantalla plasma del ordenador y de la televisión, del teléfono móvil. La vida misma está en pantalla, un ejemplo de ello se aprecia en El sbow de Truman (Peter Weir, 1998), donde se mostró la pantalla como el oxímoron, como la combinación contradictoria de elementos que terminan dando un nuevo sentido a nuestra vida (Instituto Pedagógico Padres y Maestros, 2003, 49-52).

Aceptando esa realidad audiovisual, hay que comprenderla y sobre todo interpretarla y ella no sólo es factible aprenderla a partir de un método sumativo, es decir, juntando letras sino que el estudio de la imagen requiere un enfoque total, necesita de un método global para el mundo actual que es en sí mismo globalizado

10. Recientemente se ha participado en un debate sobre Cine e impresionismo, presentado por Roman Gubern y Santos Zunzunegui, a partir del visionado de la película Moulin Rouge (John Huston, 1952) y nos sentimos emocionados al comprobar cómo una considerable parte del foro allí asistente aplaudió calurosamente ante una escena determinada de la película en señal de empatía y solidaridad con la actitud del protagonista, José Ferrer (representando a Toulouse Lautrec). Una vez más, se reafirma el carácter de la comunicación cinematográfica (Ciclo de Cine. Cine e impresionismo. Fundación Barrié de la Maza. Vigo, 12 de mayo de 2006, de 20 a 23 horas). 
(González, 2004; Gabelas, 2005). Y por ello defendemos la necesidad de enseñar a analizar seriamente la imagen, para saber leerla y comprenderla.

Debemos partir de las imágenes que se ven a diario y deconstruirlas para poder entender cuáles son las que reflejan las emociones y la realidad que debemos conocer y las que tendenciosamente impiden el crecimiento personal y creativo tal como sucede en la actualidad, por ejemplo, con el consumo de determinadas sustancias, que nos prometen valores ficticios provocando el desmérito, la invalidez y hasta el aniquilamiento personal ${ }^{11}$.

A este respecto, Gubern (2005) nos señala claramente que se está produciendo un cambio en el cine y ello debe motivar más a una pedagogía con el cine. De aquellas salas inmensas, en donde cabían centenares de espectadores, se está pasando a las minisalas intimistas; y a la concepción del cine como elemento de masas, que aún se sostiene con las películas de Steven Spielberg, George Lucas o Ridley Scott para dar entrada a un cine digital de dagas y personajes voladores o impresionantes ejércitos mecánicos repetidos por ordenador, El señor de los anillos (Peter Jackson, 2001) o deslumbrantes trucos digitalizados, Harry Potter (Chris Columbus, 2001) todo ello ofrece un escenario para entender que el cine de hoy es un medio más de socialización y por ello de aprendizaje, donde la intervención pedagógica puede aprovechar su imagen para hacer llegar o profundizar en el conocimiento. Y como siempre ha ocurrido, existirá un cine de masas, de entertainement, que, compaginará con un cine más intimista como el de Víctor Erice, Von Trier, Ken Loach o Angelopoulos u otros estilos combinados como el de Woody Allen, Joel Coen o Pedro Almodóvar, entre otros; lo mismo que acontece con el conocimiento y su profundización, ahora que se habla tanto de educar en competencias.

Esta gama de pluralidad y riqueza de aprendizaje que nos oferta el cine es un magnífico trampolín para explicar la búsqueda de nuevas posibilidades y mejoras personales, un reto por el cual merece la pena seguir luchando y apostando.

\section{UN MODELO DE PROGRAMA DE INTERVENCIÓN PEDAGÓGICA DE ALFABETIZACIÓN EMOCIONAL A TRAVÉS DEL CINE}

Desde el principio de la educación para la vida y la importancia del desarrollo integral de los individuos buscamos llegar a la totalidad de la personalidad de los individuos a través del cine. El cine es el medio que entrelaza las diferencias individuales como espectador con los elementos comunes que posee como ser humano sociable. Estos dos planos configuran la posibilidad de que las personas ejerciten emociones, sentimientos, percepciones, juicios y el espíritu crítico. Todas

11. Deconstruir la actualidad, entrevista a Jacques Derrida (PuSSAGES, 1993, 57, 60-75), www.personales.ciudad.com.ar /Derrida/artefactualidades.htm. (Página consultada, 13 de febrero de 2006). 
estas consideraciones nos conducen a la búsqueda de estilos pedagógicos adecuados para su realización.

En esta parte del artículo, con un enfoque eminentemente práctico, quisiéramos exponer lo que constituye el objetivo central del mismo: la necesidad de la alfabetización emocional y las posibilidades que ofrece el cine para llevarla a cabo. Para ello, y de forma escueta, comenzaremos por recordar la importancia de la emoción y de su educación para posteriormente presentar dos formas de contribuir a ella. La primera consistiría en el análisis de una escena de una película. Por sus características permitiría una intervención pedagógica tanto en cualquier ámbito de la educación social como en el sistema educativo (Sarramona, Vázquez y Colom, 1998; Colom, 2005). La segunda pretende lograr una mayor continuidad y busca una estructuración más sistemática y organizada. Se prestaría a ser todo un programa de alfabetización emocional a través del cine.

Con respecto a la importancia de la emoción y de su educación, no es necesario advertir que todos constantemente experimentamos reacciones corporales, de carácter subjetivo, en parte innatas y en parte adquiridas, en relación a lo que percibimos como positivo o negativo para nuestra persona. En ellas se integran conocimientos, actitudes y creencias que nos sirven para valorar situaciones, expectativas, recuerdos, deseos, percepciones...

Desde siempre la educación ha concedido una gran relevancia a la expresión de las emociones e incluso, en nuestra cultura, especialmente en determinados ambientes o sectores sociales, se ha considerado de mala educación su manifestación espontánea y se ha inculcado su control y hasta su represión e incluso castigo. Este planteamiento derivaba de la identificación de la persona con su componente racional y del menosprecio hacia lo afectivo. Sin embargo, como ya hemos indicado, la visión unitaria del ser humano, la aceptación de su complejidad, han llevado recientemente a destacar la importancia de la emoción tanto en lo personal como en lo social y laboral. No vamos a insistir de nuevo en la trascendencia que han alcanzado los estudios sobre la inteligencia emocional.

Para justificar la dedicación de los educadores y educadoras a la alfabetización emocional bastaría, por lo tanto, el reconocimiento del peso que para las personas y su felicidad, para su vida social y laboral tiene la emoción. Pero deberíamos añadir, además, que nuestra época y cultura, fuertemente inclinadas hacia la permisividad y la espontaneidad, reclaman que en la formación de la persona se conceda una prioridad aún mayor a la educación de la emoción. Para ello habrá que impartir conocimientos teóricos y prácticos sobre la vida emocional; pero sobre todo se deberá revivir emociones, analizarlas, comprenderlas, y aprender a potenciar todo lo positivo que hay en ellas, así como a dominar y sublimar sus derivaciones negativas (Gutiérrez Moar, 1998, 2002, 2004; Marina, 2000; Bisquerra, 2001, 2003a, 2003b, 2003c; Álvarez, 2001; Pascual y Cuadrado, 2001; Gómez i Bruguera, 2003; Güel y Muñoz, 2003; López, 2003; Renóm, 2003; Punset, 2004, 2005; Baena, 2005). En esta tarea nos parece que el cine puede convertirse en un recurso pedagógico 
EL CINE COMO INSTRUMENTO DE ALFABETIZACIÓN EMOCIONAL

de una potencialidad excepcional y es por eso por lo que brindamos dos modelos para posibles intervenciones pedagógicas.

\subsection{Análisis de una secuencia cinematográfica}

El primer modelo consistiría en la utilización para la alfabetización emocional de una escena cinematográfica. Como hemos dicho, por la posibilidad de su uso de forma ocasional, asistemática, se prestaría a ser utilizada en cualquier ámbito, ya sea en los que son propios de la educación social, no formal o extraescolar, ya sea dentro del sistema educativo, o formal. Compaginaría el valor de la lectura y del visionado cinematográfico. De este modo, atenderíamos las advertencias de Sartori ya citadas, frente a la capacidad emocional de la imagen, muy superior a la de la palabra (Gubern, 2006), pues la lectura permite una consideración más reflexiva y distanciada, un análisis más intelectual, una atención más pausada de todos los factores y elementos y hasta una posterior verbalización y redacción escrita de pensamientos y conclusiones. Entre otras, algunas de las ventajas que supondría trabajar una escena de un film serían: centrarnos en un momento de especial intensidad emocional; aprovechar de forma minuciosa toda la riqueza que encierran unos minutos en lugar de la hora y media, aproximadamente, que suele durar un film; interpretar profundamente la relación entre texto y recursos fílmicos con todas las posibles transferencias que supondrá respecto a otros mensajes visuales (otras películas, espacios de televisión, publicidad...).

A modo de ejemplo que perfectamente puede ser adaptado a otras escenas, vamos a mostrar un modelo de intervención pedagógica ${ }^{12}$ con una secuencia de la película Te doy mis ojos, de Icíar Bollaín, estrenada en el año $2003^{13}$. Una vez expuesta la sinopsis de la trama, en primer lugar, ofrecemos unos diálogos escritos extraídos del guión cinematográfico cuya lectura se llevaría a cabo inmediatamente antes de la proyección de la escena (para facilitar una visión más orientada y sosegada). En segundo lugar, unas pautas para la reflexión.

\section{a) Una breve exposición del argumento}

Pilar huye atemorizada de su casa una noche de invierno con su hijo Juan. Tras nueve años de matrimonio, se replantea el constante maltrato al que la somete su marido, Antonio. Éste consciente de su amor posesivo y de la actuación inadecuada hacia su mujer decide acudir a una terapia, pero ello no impide que la siga acosando. A la par se van tejiendo las historias familiares de los diversos personajes que

12. Nos decidimos por esta escena concreta porque fue una de las más elegidas, emocionalmente, entre la muestra de alumnado que hemos trabajado.

13. www.labutaca.net/51sansebastian/tedoymisojos.htm. (Página consultada, 13 de febrero de 2006). www.zinema.com/película/2003/tedoymis.htm. (Página consultada, 13 de febrero de 2006). 
rodean a los protagonistas y recomponen el entramado cinematográfico. Nos encontramos ante una vidriosa realidad que aborda el tema de las mujeres maltratadas.

b) Descripción de la secuencia

El encuadre de esta escena es realista y se caracteriza porque no hay música de fondo, sólo los sonidos-ruidos típicos del ambiente que describiremos: voces en tono normal y con tendencia a elevarse, gritos, gemidos, llantos, golpes, silencios... procedentes del hogar típico de una pareja joven de clase media baja. Los planos son cortos y los movimientos de cámara se muestran rápidos, como si nos invadieran, predominando los primeros planos y medios o americanos y algún plano general y de detalle. La iluminación es prioritariamente natural, común del interior de una vivienda sencilla y ordenada, en una zona nueva a las afueras de la ciudad histórica de Toledo, y de unos personajes que viven unas emociones muy concretas, que nos interesa analizar y reflexionar.

c) Guión

(Antonio se levanta del sofá, después de dormir toda la noche en él y de comprobar que Pilar, su mujer, acaba de pasar sigilosamente a coger la ropa que tenía preparada y colgada de un tirador del mueble del salón. La había planchado cuidadosamente el día anterior para llevarla en el viaje a Madrid para realizar una entrevista de selección de trabajo para un museo. Mientras se acerca a ella, ésta se pone los pendientes, callada y sumisa, de espaldas a él).

Antonio: ¿Asi que te vas a eso...?

Pilar: Si (Con voz baja, temerosa, presintiendo cuanto va a acontecer...).

Antonio: ;Mirame cuando te bablo! (En tono enérgico).

Antonio: ;Vuélvete! ;Vaya pinta! (De modo despectivo).

Pilar: Quiero estar presentable.

Antonio: Si, que te vean ¿no? Eso es lo que te enrolla, que te vean. 'Mentirosa!

Pilar: Yo no be dicho eso. Puedes venir al Museo cuando quieras. (Sigue manteniendo el tono suave).

Antonio: ¡No sé qué baces cuando los cuadros! ¿Quieres ponerte por abi, que vean lo guapa que eres y te vean las piernas y el culo...?

(De forma insistente suena el timbre del telefonillo del portal, llaman a Pilar para ir a Madrid. Antonio va incrementando el clima de tensión).

Pilar: Antonio, me están esperando...

(Éste se altera progresivamente e insiste ante las láminas del libro de arte que le había regalado a Pilar para que se las comente ahora como hace con el público visitante del Museo. A medida que pasa las imágenes de la obra va dando argumentos fuera de tono e irrespetuosos asociados a su trabajo y hacia las figuras artísticas, va arrancando, arrugando y tirando al suelo las páginas del libro, de forma brusca. A Pilar le invade el miedo que va en aumento, el terror y la impotencia, y 
va dando pasos hacia atrás mientras él la va oprimiendo cada vez más verbal, física y psíquicamente).

Antonio: ¿Te enrolla que te vean las tetas y el culo? ¿Es lo que te enrolla, no? Pilar: Antonio... iNo! iNo!

(El marido la coge bruscamente y le abre la blusa sin control. Ella está medio consternada; él continúa empujándola y cae al suelo, y aprovecha para seguir desvistiéndola hasta que queda en sujetador medio puesto. Pilar se retuerce, grita y se resiste pero él la levanta, abre la puerta del balcón del salón y la empuja con fuerza hacia fuera. Ésta queda aterrorizada e intenta taparse, indefensa).

Antonio: ¿No bay público abora suficiente? ¡Te está viendo todo Dios! ¿Estás contenta, te han visto todos los vecinos?

(Chilla desesperado ante la actitud infrahumana y vejatoria por la que está haciendo pasar a su mujer).

Pilar: ¡No, no! ¡Ábreme...!

(Frente a esta situación insostenible, Pilar grita y llora angustiada. Antonio abre la puerta y coge a Pilar por los pelos y la adentra en casa. Ella queda bloqueada, en estado de shock, sin palabras, medio gimiendo; su cuerpo rígido tiembla y su boca abierta y ojos desencajados anuncian que por sus piernas se desliza la orina que no ha podido contener. Algo que jamás le había sucedido. La cámara en picado nos narra este acto estremecedor y patético. De nuevo, Antonio, ante lo presenciado, retoma la calma, estupefacto, suelta a Pilar y le comenta: Anda, lávate. Frente a tal desolación, la protagonista recobra el llanto resquebrajado, se escurre y queda medio sentada y derrumbada en el suelo) (Bollaín y Luna, 2003).

La lectura de los textos permite captar de forma consciente, racional y serena la secuencia seleccionada. Posiblemente nadie quede indiferente después de su lectura pero no se encontrará tan afectado, impresionado, emocionado como sucedería con el simple visionado. Una vez leídos individualmente los textos, se procedería a una reflexión personal o compartida que podría preceder a la proyección de la escena. Ofrecemos, a modo de ejemplo, algunas ideas para esa reflexión (González Martell, 1996; Casanova, 1998).

\section{a) Complejidad-realismo}

En este caso es importante aprovechar que la presentación del problema de la violencia contra la esposa se hace asumiendo toda la complejidad que tiene esta problemática en la realidad. Los personajes son absolutamente reales, normales, podríamos intercambiarlos por personas con las que nos encontramos habitualmente en nuestra vida ordinaria. Y esto nos permite comprender que las soluciones a los problemas emocionales (y más aún si están vinculados a pautas y modelos culturales) no son fáciles ni sencillas. Están decididos a ser pareja pero mientras que él se refugia en un modelo machista, de imposición y control desmedido de la mujer hasta su anulación como persona si ello va contra su sentido de posesión, 
ella se resiste a reproducir la conducta de su madre y quiere compaginar su función de esposa y madre con su desarrollo personal en una profesión que le atrae y para la que se siente preparada. Elementos sugerentes en la escena son "los dos Toledos" (el histórico y el moderno al que pertenece el hogar que se nos muestra) como contraposición de modelos de pareja pasados y actuales que chocan; la rotura de un libro de arte (estética, belleza, sensibilidad); la brutalidad de la ira por parte de Antonio y la mansedumbre y el sometimiento con el que ella, presa del miedo, reacciona tratando de aplacarle o al menos de evitar su violencia; el desenlace, que puede ser un exponente más de esa complejidad (triunfa la mujer débil y queda humillado y derrotado el hombre fuerte) o tan sólo una concesión a la esperanza y al gusto o pretensión de los espectadores de contemplar un final deseado, esperanzado y feliz. Un horizonte ilimitado.

\section{b) Las contraposiciones}

Las emociones son bipolares, positivas o negativas. La secuencia nos ofrece un buen número de contraposiciones que nos permiten hacer llamadas a la posibilidad de optar y de avanzar en un sentido o en el contrario. En ella encontramos diversidades: seguridad/libertad como un dilema al que ha de enfrentarse cualquier persona acosada, presionada; sumisión/realización personal, a pesar de los bloqueos constantes; pautas tradicionales y confortables si se siguen plenamente/nuevas formas de vida acordes con la sociedad actual y sus valores, atractivas pero que suponen rupturas y riesgos. En él observamos: amar a otra persona desde el respeto y la aceptación de su libertad/exigir que se pliegue a sus concepciones machistas, de dominio absoluto, de que no le suponga superar su inseguridad y sus miedos infundados al comportamiento que ella tendrá "en libertad". También contraposición entre hogar como lugar del desarrollo personal, de la satisfacción y la realización propia/hogar como cárcel, como jaula, como "burka" donde se controla a la mujer, se reduce su espacio vital hasta la asfixia, donde ha de temer un castigo si pretende ser o actuar al margen de los deseos del imperio masculino; dificultades insalvables de una pareja donde el varón no controla su inseguridad, su desconfianza, sus celos y su ira frente a la normalidad con que funciona la pareja de la hermana de Pilar, casada con un extranjero, en un ambiente democrático, abierto y tolerante.

\section{c) Problemática del mundo emocional}

La reflexión sobre la escena, lejos de llevarnos hacia actitudes hipócritas, permite enlazar con experiencias personales y comprobar que en los sentimientos y emociones encontramos vivencias gratas pero que, por lo general, supondrán exigencias si queremos mantenerlas y cultivarlas. La secuencia invita a que pensemos y comentemos en común sobre comportamientos personales en los que hemos experimentado temor/amor; furia/serenidad; egoísmo/altruismo; dominio/humillación; libertad/sumisión; pena/alegría; ilusión/desencanto... 
d) Encuentro-desencuentro entre formas masculinas y femeninas, entre modelos tradicionales y actuales de familia, pareja, hogar, estilos de vida, y toda la jerarquía de valores que cada modelo conlleva... (Sastre, 2002; Ortega y Mínguez, 2003; Rodríguez y Peña, 2005).

e) Análisis de los comportamientos y sentimientos de los protagonistas para trasladarlos a otras situaciones

Por parte de Antonio: la ira, los celos, el deseo de dominar o destrozar (el típico dicho "si no eres mía no lo serás de nadie"), el deterioro simbólico del libro que representa su nueva vida, su "imagen", su "persona", sus formas de vestir, lo que es ante los demás; el ensuciar y minusvalorar con sus palabras e insultos, el desfigurar su modo de ser y de actuar hasta transformarla en pura ignominia; atemorizarla hasta la regresión al descontrol corporal, el sentimiento de vergüenza.

Por parte de Pilar: su actuación discreta y silenciada; la mansedumbre, sumisión exterior, intento de no aplacar su irritación, súplica, evitar el enfrentamiento directo, consciente de la pérdida del diálogo y el entendimiento mutuo, silencio, llanto... Pero en cuanto él deje un resquicio, comprendiendo que es vano esperar un cambio en las emociones y actitudes de él, abandono, a pesar de lo que se le ha querido, de lo que significa, de quien no es capaz de respetarle, de ofrecer estima, de quererle como persona y de sentir compasión (Lorente, 2001, 2004; Segura y Arcas, 2003).

Y por ello, nos cuestionamos, ¿todo esto sólo se evidencia en las relaciones de pareja?, ¿no hay otras relaciones donde también se puede dar aunque sea en forma e intensidad diferentes?

f) El mensaje del título

El título del film no es casual, Te doy mis ojos que Antonio dice que le ha dado a Pilar, los "ojos" son, dice la sabiduría popular, las ventanas del alma. Y es a través de secuencias como ésta donde se puede educar a la adolescencia y juventud, de ambos sexos, en el respeto a la esencia del ser humano, sea del sexo y opción que sea, los unos, para no violar esa esencia y las otras, para defenderla y no caer en la inanidad del terror que aniquila hasta lo físico y se vuelve incontrolable.

g) El dilema al que se han de enfrentar muchas mujeres en el mundo actual

Al hilo de la cuestión meditamos también sobre la frase de Shirin Evadi, iraní y premio Nobel de la Paz, de 2003: “Vivir donde se desee, escribir lo que se piensa, vestir como se prefiera, amar a quien se ame y tener derecho a elegir la religión que ilumina una vida con el único límite del respeto a los otros ${ }^{14}$.

14. Tomada de Alborch $(2004,147)$. Sugerente testimonio biográfico, se expone el deseo de ser libre sin más límite que el respeto al otro. Si en otros momentos de la historia se ha impuesto a las 
Como espectadores nos damos cuenta de que la violencia de género no la podemos seguir mirando ni analizando con ojos de la permisividad machista. $O$ volviendo la vista hacia otra dirección. Alli se juega la esencia del ser humano.

\subsection{Un programa de alfabetización emocional}

Incluimos a continuación una propuesta de intervención pedagógica en la que combinamos Derechos Humanos (fundamental en nuestro quehacer de educación en valores), alfabetización audiovisual y educación emocional (Valero, 1992; Gil, Jover y Reyero, 2001; Escámez y Gil, 2001; García Moriyón, 2003; Martínez, Puig y Trilla, 2003; Hoyos y Martínez, 2004; Naya, 2005; Ugarte, 2005; Cobo, 2005). La venimos experimentando en Educación Secundaria (asociados a profesorado de este nivel) y en nuestras clases de Educación Social y Psicopedagogía. La metodología no ha sido uniforme pues hemos tenido que adaptarla a las circunstancias concretas de cada nivel y de la docencia. Dentro de ella, se ha seleccionado a 32 películas diferentes por muchas razones pero que se prestaban a trabajar la educación en valores y la educación emocional; se ha indagado sobre las escenas/secuencias que recordaban por el impacto emocional que les habían causado; se ha comprobado sus conocimientos y formación cinematográfica (asombrosamente escasa); se han proyectado algunas películas y se le ha pedido al alumnado que seleccionen la escena para ellos más sobresaliente y describan las emociones y sentimientos que su visión les había suscitado; se ha trabajado por grupos y desarrollado puestas en común. Una primera comprobación ha sido la elevada coincidencia en las escenas/secuencias seleccionadas y que mostramos en el cuadro que ponemos a continuación de la lista de las películas elegidas (Loscertales y Núñez, 2001; Martínez-Salanova, 2002; Alegre, 2003; Martínez, 2003; Almacellas, 2004; Pereira, 2005a, 2005b; Prats, 2005).

1. American History, Tony Kaye, USA, 1998.

2. Billy Elliot (Quiero bailar), Stephen Daldry, Reino Unido, 2000.

3. Buscando a Nemo, Andrew Stanton y Lee Unkrich, USA, 2003.

4. Cadena de favores, Mimi Leder, USA, 2000.

5. Cadena perpetua, Frank Darabont, USA, 1994.

6. Cinema Paradiso, Giuseppe Tornatore, Italia, 1988.

7. El Bola, Achero Mañas, España, 2000.

8. El cartero y Pablo Neruda, Michael Radford, Italia, Francia, 1995.

9. El caso Winslow, David Mamet, Reino Unido, 1999.

10. El chico, Charles Chaplin, USA, 1921.

11. El club de los poetas muertos, Peter Weir, USA, 1989.

mujeres su identificación con la seguridad, la sumisión, ahora éstas quieren también entender su desarrollo como persona, como libertad, como coherencia con lo que se quiere y se siente. 
12. El pianista, Roman Polanski, Francia, Alemania, Reino Unido, Polonia y Holanda, 2002.

13. El piano, Jane Campion, Australia, Nueva Zelanda, Francia, 1993.

14. El Rey León, Rogers Allers y Rob Minkoff, USA, 1994.

15. Habana Blue, Benito Zambrano, España, Cuba, Francia, 2005.

16. Hoy empieza todo, Bertrand Tavernier, Francia, 1998.

17. La lengua de las mariposas, José Luis Cuerda, España, 1999.

18. La vida es bella, Roberto Benigni, Italia, 1997.

19. Lloviendo piedras, Ken Loach, Reino Unido, 1993.

20. Los chicos del coro, Christophe Barratier, Francia, Suiza, Alemania, 2004.

21. Los olvidados, Luis Buñuel, México, 1950.

22. Mar adentro, Alejandro Amenábar, España, 2004.

23. Million dolars baby, Clint Eastwood, USA, 2004.

24. Mi nombre es Joe, Ken Loach, Reino Unido, 1998.

25. Osama, Siddiq Barmak, Afganistán, Holanda, Japón, Irlanda, 2003.

26. Ser y tener, Nicolás Philibert, Francia, 2002.

27. Shrek, Andrew Adamson y Vicky Jenson, USA, 2001.

28. Solas, Benito Zambrano, España, 1998.

29. Te doy mis ojos, Icíar Bollaín, España, 2003.

30. Tiempos modernos, Charles Chaplin, USA, 1936.

31. Un lugar en el mundo, Adolfo Aristaraín, Argentina, 1992.

32. Yo soy Sam, Jessie Nelson, USA, 2001.

Además, queremos matizar que de todo este compendio de películas predomina el género dramático y documental, y comprende una gran gama, desde el cine mudo hasta el de animación, pasando por el documental, bélico, de ficción, musical, suspense, comedia... También, se tratan variedad de filmes desde los más punteros, elaborados con los últimos avances del mundo del celuloide, hasta los más puramente artesanales, con los mínimos recursos técnicos, económicos y humanos pero colmados de gran profesionalidad, creatividad y compromiso social. 
Cuadro 2. DeRechos humanos, CINE y eduCación EMocional

\begin{tabular}{|c|c|c|c|}
\hline $\begin{array}{c}\text { Derechos Humanos } \\
\text { para educar en } \\
\text { valores }\end{array}$ & $\begin{array}{c}\text { Peliculas } \\
\text { seleccionadas }\end{array}$ & Escenas de interés & $\begin{array}{l}\text { Emociones para } \\
\text { la reflexión }\end{array}$ \\
\hline \multirow[t]{3}{*}{$\begin{array}{l}\text { 1. Los seres humanos } \\
\text { libres e iguales } \\
\text { (arts. } 1 \text { y } 2 \text { ). }\end{array}$} & 1.1. American History. & $\begin{array}{l}\text { 1.1. Golpe al chico } \\
\text { negro contra el bordillo } \\
\text { de la acera. }\end{array}$ & $\begin{array}{l}\text { 1.1. Miedo, terror, nacen } \\
\text { conmoción, humillación. }\end{array}$ \\
\hline & 1.2. El pianista. & $\begin{array}{l}\text { 1.2. El protagonista } \\
\text { toca el piano ante el } \\
\text { guardia alemán. }\end{array}$ & $\begin{array}{l}\text { 1.2. Tristeza, } \\
\text { compasión, pesar. }\end{array}$ \\
\hline & 1.3. La vida es bella. & $\begin{array}{l}\text { 1.3. El niño presencia } \\
\text { la muerte de su padre } \\
\text { sin enterarse. }\end{array}$ & $\begin{array}{l}\text { 1.3. Diversión, alegría } \\
\text { tristeza, y abatimiento. }\end{array}$ \\
\hline \multirow{2}{*}{$\begin{array}{l}\text { 2. Derecho a la vida, } \\
\text { a la libertad y a la salud } \\
\text { (arts. } 3 \text { y } 4 \text { ). }\end{array}$} & 2.1. El Rey León. & $\begin{array}{l}\text { 2.1. Ante su padre } \\
\text { muerto. }\end{array}$ & $\begin{array}{l}\text { 2.1. Pena, aflicción, } \\
\text { soledad, adoración. }\end{array}$ \\
\hline & 2.2. Mar adentro. & $\begin{array}{l}\text { 2.2. Se despide de } \\
\text { su familia. }\end{array}$ & $\begin{array}{l}\text { 2.2. Desesperación, } \\
\text { alegria, comprensión. }\end{array}$ \\
\hline \multirow[t]{3}{*}{$\begin{array}{l}\text { 3. Derechos jurídicos } \\
\text { (arts. } 5 \text { a 11). }\end{array}$} & 3.1. Cadena perpetua. & $\begin{array}{l}\text { 3.1. El viejo presidiario } \\
\text { sale de la cárcel. }\end{array}$ & $\begin{array}{l}\text { 3.1. Compasión, soledad } \\
\text { indignación, lástima, } \\
\text { vergüenza. }\end{array}$ \\
\hline & 3.2. El caso Winslow. & $\begin{array}{l}\text { 3.2. Al final, el abogado } \\
\text { expresa sus sentimientos } \\
\text { ante la chica. }\end{array}$ & $\begin{array}{l}\text { 3.2. Aceptación, alivio, } \\
\text { satisfacción, amor. }\end{array}$ \\
\hline & 3.3. Mi nombre es joe. & 3.3. Al borde del suicidio. & $\begin{array}{l}\text { 3.3. Tristeza, abatimiento, } \\
\text { remordimiento, temor, } \\
\text { soledad. }\end{array}$ \\
\hline $\begin{array}{l}\text { 4. Derecho a circular } \\
\text { libremente (arts. } 13 \text { a 15). }\end{array}$ & 4.1. Habana Blue. & $\begin{array}{l}\text { 4.1. La despedida y fuga } \\
\text { en la lancha. }\end{array}$ & $\begin{array}{l}\text { 4.1. Compasión, tristeza, } \\
\text { amor, remordimiento, } \\
\text { culpabilidad, alivio. }\end{array}$ \\
\hline \multirow{4}{*}{$\begin{array}{l}\text { 5. Derecho a formar } \\
\text { libremente un } \\
\text { matrimonio y una } \\
\text { familia (art. 16). }\end{array}$} & 5.1. El piano. & 5.1. La mutilación. & $\begin{array}{l}\text { 5.1. Indignación, tristeza, } \\
\text { miedo, ansiedad, conmoción, } \\
\text { alivio, desesperación. }\end{array}$ \\
\hline & 5.2. Osama. & 5.2. La prueba del pozo. & $\begin{array}{l}\text { 5.2. Horror, autocompasión, } \\
\text { desconcierto. }\end{array}$ \\
\hline & 5.3. Solas. & $\begin{array}{l}\text { 5.3. El embarazo y la } \\
\text { actitud de su pareja. }\end{array}$ & $\begin{array}{l}\text { 5.3. Furia, fastidio, } \\
\text { indignación, } \\
\text { desesperación, soledad. }\end{array}$ \\
\hline & 5.4. Te doy mis ojos. & $\begin{array}{l}\text { 5.4. La prohibición de } \\
\text { viajar a Madrid. }\end{array}$ & $\begin{array}{l}\text { 5.4. Temor, pena, } \\
\text { autocompasión, furia, } \\
\text { humillación. }\end{array}$ \\
\hline $\begin{array}{l}\text { 6. Derecho a la propiedad } \\
\text { (art. 17). }\end{array}$ & 6.1. Un lugar en el mundo. & 6.1. La clase de geología. & $\begin{array}{l}\text { 6.1. Embeleso, satisfacción, } \\
\text { adoración, confianza, } \\
\text { orgullo, asombro. }\end{array}$ \\
\hline $\begin{array}{l}\text { 7. Derechos políticos. } \\
\text { Derecho a la libertad de } \\
\text { ideas (arts. } 18 \text { a 21). }\end{array}$ & $\begin{array}{l}\text { 7.1. El cartero y Pablo } \\
\text { Neruda. }\end{array}$ & $\begin{array}{l}\text { 7.1. El poeta graba sus } \\
\text { vivencias para su pueblo. }\end{array}$ & $\begin{array}{l}\text { 7.1. Melancolía, amor, } \\
\text { adoración, tristeza, } \\
\text { confianza. }\end{array}$ \\
\hline
\end{tabular}




\begin{tabular}{|c|c|c|c|}
\hline \multirow[t]{2}{*}{$\begin{array}{l}\text { 8. Derecho al trabajo } \\
\text { y a una vida digna } \\
\text { (arts. } 22 \text { a } 25 \text { ). }\end{array}$} & 8.1. Lloviendo piedras. & $\begin{array}{l}\text { 8.1. El protagonista se } \\
\text { sincera con el Pastor. }\end{array}$ & $\begin{array}{l}\text { 8.1. Ira, remordimiento, } \\
\text { disgusto, pena, temor, } \\
\text { confianza. }\end{array}$ \\
\hline & 8.2. Tiempos modernos. & $\begin{array}{l}\text { 8.2. Probando la nueva } \\
\text { máquina. }\end{array}$ & $\begin{array}{l}\text { 8.2. Alegría, diversión, } \\
\text { simpatía, incertidumbre. }\end{array}$ \\
\hline \multirow[t]{6}{*}{$\begin{array}{l}\text { 9. Derecho a la } \\
\text { maternidad y a la } \\
\text { infancia (art. 25.2). }\end{array}$} & 9.1. Buscando a Nemo. & $\begin{array}{l}\text { 9.1. El ataque de los } \\
\text { tiburones. }\end{array}$ & $\begin{array}{l}\text { 9.1. Tristeza, desolación, } \\
\text { temor, compasión, pena, } \\
\text { amor. }\end{array}$ \\
\hline & 9.2. El chico. & $\begin{array}{l}\text { 9.2. Los guardias se } \\
\text { llevan a la niña. }\end{array}$ & $\begin{array}{l}\text { 9.2. Desesperación, } \\
\text { melancolía, incomprensión, } \\
\text { tristeza, disgusto. }\end{array}$ \\
\hline & 9.3. El Bola. & $\begin{array}{l}\text { 9.3. El protagonista } \\
\text { declara ante la policía. }\end{array}$ & $\begin{array}{l}\text { 9.3. Ira, humillación, } \\
\text { temor, alivio, repulsión. }\end{array}$ \\
\hline & 9.4. Los chicos del coro. & $\begin{array}{l}\text { 9.4. El coro canta ante la } \\
\text { benefactora y el maestro } \\
\text { da entrada al solista. }\end{array}$ & $\begin{array}{l}\text { 9.4. Asombro, arrepenti- } \\
\text { miento, alegría, confianza, } \\
\text { embeleso. }\end{array}$ \\
\hline & 9.5. Million dolars baby. & $\begin{array}{l}\text { 9.5. La familia reivindica } \\
\text { los bienes de la hija. }\end{array}$ & $\begin{array}{l}\text { 9.5. Indignación, ira, } \\
\text { humillación, desconcierto. }\end{array}$ \\
\hline & 9.6. Yo soy Sam. & $\begin{array}{l}\text { 9.6. La niña reconoce las } \\
\text { limitaciones de su padre. }\end{array}$ & $\begin{array}{l}\text { 9.6. Amor, adoración, } \\
\text { diversión, aceptación. }\end{array}$ \\
\hline \multirow{7}{*}{$\begin{array}{l}\text { 10. Derecho a la } \\
\text { educación, a la cultura, } \\
\text { a las artes y a las } \\
\text { ciencias (arts. } 26 \text { y 27). }\end{array}$} & 10.1. Billy Elliot. & $\begin{array}{l}\text { 10.1. El estreno de la } \\
\text { danza en el teatro. }\end{array}$ & $\begin{array}{l}\text { 10.1. Orgullo, confianza, } \\
\text { amor, alegría, satisfacción. }\end{array}$ \\
\hline & 10.2. Cinema Paradiso. & $\begin{array}{l}\text { 10.2. Al final se recuerdan } \\
\text { las películas, escenas y } \\
\text { experiencias de la infancia. }\end{array}$ & $\begin{array}{l}\text { 10.2. Alegría, melancolía, } \\
\text { orgullo, adoración. }\end{array}$ \\
\hline & $\begin{array}{l}\text { 10.3. El club de los poetas } \\
\text { muertos. }\end{array}$ & $\begin{array}{l}\text { 10.3. La despedida del } \\
\text { profesor. }\end{array}$ & $\begin{array}{l}\text { 10.3. Pena, fastidio, } \\
\text { afecto, compasión, } \\
\text { devoción. }\end{array}$ \\
\hline & 10.4. Hoy empieza todo. & $\begin{array}{l}\text { 10.4. El desplome del } \\
\text { docente ante el drama } \\
\text { familiar ocurrido. }\end{array}$ & $\begin{array}{l}\text { 10.4. Indignación, tristeza, } \\
\text { desolación, conmoción, } \\
\text { amor, remordimiento. }\end{array}$ \\
\hline & $\begin{array}{l}\text { 10.5. La lengua de las } \\
\text { mariposas. }\end{array}$ & $\begin{array}{l}\text { 10.5. El arresto de personas } \\
\text { contrarias al régimen } \\
\text { político. }\end{array}$ & $\begin{array}{l}\text { 10.5. Ira, congoja, } \\
\text { asombro, desprecio, } \\
\text { humillación, soledad, afecto. }\end{array}$ \\
\hline & 10.6. Ser y tener. & $\begin{array}{l}\text { 10.6. El maestro se } \\
\text { preocupa por la salud } \\
\text { del padre de un alumno. }\end{array}$ & $\begin{array}{l}\text { 10.6. Aceptación, } \\
\text { confianza, abatimiento, } \\
\text { amor, pena, pesimismo. }\end{array}$ \\
\hline & 10.7. Shrek. & $\begin{array}{l}\text { 10.7. Shrek y Asno } \\
\text { discuten. }\end{array}$ & $\begin{array}{l}\text { 10.7. Desconcierto, } \\
\text { pena, simpatía, } \\
\text { aceptación, alegría. }\end{array}$ \\
\hline \multirow{2}{*}{$\begin{array}{l}\text { 11. Derecho a un orden } \\
\text { social que permita el } \\
\text { ejercicio de los derechos } \\
\text { humanos. Deberes } \\
\text { con la comunidad } \\
\text { (arts. } 28 \text { y 29). }\end{array}$} & 11.1. Cadena de favores. & 11.1. La muerte del niño. & $\begin{array}{l}\text { 11.1. Tristeza, compasión, } \\
\text { indignación, disgusto, } \\
\text { conmoción, alivio. }\end{array}$ \\
\hline & 11.2. Los olvidados. & $\begin{array}{l}\text { 11.2. Al final, en el } \\
\text { basurero. }\end{array}$ & $\begin{array}{l}\text { 11.2. Pena, ira, } \\
\text { preocupación, } \\
\text { resignación, } \\
\text { humillación, repulsión, } \\
\text { estremecimiento. }\end{array}$ \\
\hline
\end{tabular}




\section{Palabras finales}

Las páginas precedentes son fruto de una experiencia interuniversitaria con la finalidad de formar en valores, por la convicción de que cada vez es más importante la educación emocional de las personas - y especialmente de quienes se dedicarán a la educación- y por la comprobación de lo mucho que nos puede ayudar el cine en la tarea común.

Hemos pretendido acercarnos a la lectura, definición y vivencia de la emoción, realidad compleja, para entender la relevancia de la educación emocional de las personas. En dichas lecturas, reflexiones y vivencias nos hemos apoyado en (una referencia) las imágenes, y (una muestra) la cinematográfica que no la consideramos casual, ya que ha surgido de un estudio práctico interdisciplinar, a partir de la intervención pedagógica con el cine, dado el destacado el papel que éste tiene en nuestra realidad cultural y lo que puede significar en la conformación de los valores para entender que las emociones son los cimientos de la mente humana, y cómo el cine (se dirige), las muestra (a ellas).

El modelo de intervención pedagógica ofrecido conlleva una relación de películas seleccionadas y vinculadas a los derechos humanos, con el propósito de educar en valores, para que familias y educadores puedan ayudar a sus hijos y alumnos a enriquecerse del séptimo arte como instrumento de alfabetización audiovisual y emocional.

Creemos que este tipo de intervenciones pedagógicas favorecen aprendizajes que sensibilizan y provocan cambios de comportamiento ante los problemas sociales actuales.

Vivimos en un mundo donde la imagen se ha convertido en el gran medio de comunicación humana y nos sentimos responsables de preparar a nuestro alumnado para participar plenamente en el valor de la comunicación. Sin embargo, esta preocupación no nos lleva a la disminución de nuestro interés por intentar que no pierdan cuanto la humanidad ha construido por medio del lenguaje oral y escrito y de todos sus esfuerzos por lograr un excelente medio formativo. Nos sumamos a la idea de Stahelin (1976) que defiende la realidad de nuestra cultura, esto es, nuestro deber de ver cine, porque la película ya está incorporada a la cultura, ya que los libros y las películas educan, y los libros sin películas no expondrán el humanismo actual. Pero ello requiere aprendizaje para aprender a leer y a ver. Pues si leer no es deletrear, ver cine no consiste en mirar a la pantalla durante la proyección.

Sin afán de pretensiones modélicas, desde esta puesta en práctica animamos a las personas con sensibilidad para trabajar en intervenciones pedagógicas de este estilo porque:

- Se suscitan situaciones motivadoras hacia la formación integral.

- El análisis de secuencias cinematográficas, como las aquí expuestas, favorece la educación de la alfabetización audiovisual y emocional.

- Se propician ambientes que fomentan la comunicación y la empatía, la libertad de expresión y el respeto de las personas así como los modos de 
comportamiento acordes con nuestra jerarquía de valores. Se incide, por ello, en la formación de actitudes y valores.

- Se estimulan situaciones grupales a través de técnicas de dinámicas de grupo que mejoran el desarrollo de habilidades sociales.

- Se presentan, analizan y reflexionan pensamientos y formas de actuar que nos llevan a aceptarnos y respetarnos en una sociedad que demanda cada vez más una convivencia democrática, pacífica y tolerante.

Y sabemos que sobre la alfabetización audiovisual y emocional de los alumnos y alumnas aún queda mucho por enseñar y seguir aprendiendo; las reflexiones plasmadas en el siguiente párrafo dan fe de ello:

En el campo de conocimiento sobre el proceso de la incorporación cultural se ha dado un evidente sesgo - problemático, temático y metodológico- de orientación cognitiva. El sesgo lo representa la desproporción patente en el conocimiento acumulado respecto a la dominancia de las líneas de investigación y a la relevancia concedida a la programación emotiva (García Carrasco, Canal, Bernal y Martín, 2006, 75).

\section{BiBLIOGRAFÍA}

Aguilar, P. (1996) Manual del espectador inteligente. Madrid, Fundamentos.

Aguilló, A. (2000) Educar los sentimientos. Observar el comportamiento propio y ajeno. www.interrogantes.net. (Página consultada, 13 de febrero de 2006).

AlborCH, C. (2004) Libres. Madrid, Aguilar.

ALEGRE, O. M. ${ }^{\text {a }}$ (2003) La discapacidad en el cine. Barcelona, Octaedro.

Almacellas, M. ${ }^{a}$ A. (2004) Educar con el cine. 22 peliculas. Madrid, Ediciones Internacionales Universitarias.

ÁlVAREZ, M. y otros (coords.) (2001) Diseño y evaluación de programas de educación emocional. Barcelona, CISSPRAXIS.

AsENSIO, J. M.; ACARÍN, N. y ROMERO, C. (2006) Emociones, desarrollo bumano y relaciones educativas. Ponencia 1, XXV SITE. Universidad de Salamanca. En www.ucm.es/info/site/ 25seminario/index.htm. (Página consultada, 10 de mayo de 2006).

BAENA, G. (2005) Cómo desarrollar la inteligencia emocional: guía para padres y maestros. Alcalá de Guadaira (Sevilla), MAD.

BAUTISTA, J. M. ${ }^{\text {a }}$ y SAN José, A. I. (2002) Cine y creatividad. Madrid. FERE.

BISQUERRA, R. (2000) Educación emocional y bienestar. Barcelona, Praxis.

- (2003) Educación emocional y medios de comunicación, Comunicar, 20, 63-67.

BISQUERRA, R. y otros (coords.) (2001) Educación emocional: programa de actividades para educación secundaria obligatoria. Barcelona, CISSPRAXIS.

- (2003a) Educación emocional: programa para 3-6 años. Barcelona, CISSPRAXIS.

- Educación emocional: programa para educación primaria (6-12 años). Barcelona, CISSPRAXIS.

- (2003c) Educación emocional: programa de actividades para educación secundaria postobligatoria. Barcelona, CISSPRAXIS. 
M. ${ }^{a}$ DEL CARMEN GUTIÉRREZ MOAR, M. ${ }^{a}$ DEL CARMEN PEREIRA DOMÍNGUEZ Y LUIS FERNANDO VALERO IGLESIAS EL CINE COMO INSTRUMENTO DE ALFABETIZACIÓN EMOCIONAL

Bollaín, I. y Luna, A. (2003) Te doy mis ojos. Madrid, Ocho y Medio, Libros de Cine.

CASANOVA, O. (1998) Ética del silencio. Madrid, Alauda-Anaya.

Cово, J. M. (2005) Otro mundo es posible. Propuesta de una utopia para el siglo XXI. Madrid, Biblioteca Nueva.

Colom, A. J. (2005) Teoría del caos y práctica educativa, Revista Galega do Ensino, 47, 99-118.

COUCE, A. y otros (eds.) (2004) El reto de la educación emocional en nuestra sociedad. A Coruña, Servizo de Publicacións, Universidade da Coruña.

DAmasio, A. (2005) En busca de Spinoza: Neurobiología de la emoción y los sentimientos. Barcelona, Crítica.

Dios, M. (2001) Cine para convivir. Santiago de Compostela, ToxoSoutos.

- (2005) Educar nos afectos, frear a violencia: sobre a educación afectivo emocional. Unidade Didáctica 23, Santiago de Compostela, Seminario Galego de Educación para a Paz.

Eco, U. (2004) Historia de la belleza. Barcelona, Lumen.

EsCÁmez, J. y GIL, R. (2001) La educación en la responsabilidad. Barcelona, Paidós.

Esteve, J. M. (2003) La tercera revolución. La educación en la sociedad del conocimiento. Barcelona, Paidós.

FERRÉs, J. (2003) Educación en medios y competencia emocional, Revista Iberoamericana de Educación, 32. (Versión digital de la Revista en la OEI).

Gabelas, J. A. (2005) Por los laberintos de la imagen impresa, Quaderns Digitals, 35. www.quadernsdigitals.net. (Página consultada, 5 de mayo de 2006).

García Carrasco, J.; Canal, R.; Bernal, A. y Martín, A. V. (2006) El desorden del sistema emocional y su repercusión en la teoría y la práctica de la educación. Ponencia 2 , XXV Seminario de teoría de la Educación. SITE. Universidad de Salamanca. www.ucm.es/ info/site/seminario/index.htm. (Página consultada, 5 de mayo de 2006).

García Moriyón, F. (2003) Los derechos humanos y la educación del ciudadano, Revista de Educación, Número extraordinario: Ciudadania y educación, 109-129.

GARDNER, H. (2001) La inteligencia reformulada. Las inteligencias múltiples en el siglo XXI. Barcelona, Paidós.

- (2004) La educación de la mente y el conocimiento de las disciplinas. Lo que todos los estudiantes deberían comprender. Barcelona, Paidós.

- (2004a) Inteligencias múltiples. La teoria en la práctica. Barcelona, Paidós.

GIL, F.; Jover, G. y REYero, D. (2001) La enseñanza de los derechos humanos: 30 preguntas, 29 respuestas y 76 actividades. Barcelona, Paidós.

Goleman, D. (1996) Salud emocional. Barcelona, Kairós.

- (1998) La práctica de la inteligencia emocional: cómo llegar a ser un profesional competente. Barcelona, Círculo de Lectores.

- (2003) Inteligencia emocional (53ª edición). Barcelona, Kairós.

GómeZ, I. y BRuguera, J. (2003) Educación emocional y lenguaje en la escuela. Barcelona, Octaedro.

GONZÁlez, J. F. (2004) Aprender a ver cine. Madrid, Rialph.

González Blasco, P. (dir.) y otros (2006) Jóvenes españoles 2005. Madrid, Fundación Santa María.

GONZÁLEZ MARTELL, J. (1996) El cine en el universo de la ética. El cine-fórum. Madrid, Alauda-Anaya.

GuBERn, R. (2005) Del palacio al televisor, pasando por el minicine, Revista de Occidente, 290-291, 77-88.

- (2006) El poder invisible, El País, 12 de febrero, 17.

(C) Ediciones Universidad de Salamanca

Teor. educ. 18, 2006, pp. 229-260 
M. ${ }^{a}$ DEL CARMEN GUTIÉRREZ MOAR, M. ${ }^{a}$ DEL CARMEN PEREIRA DOMÍNGUEZ Y LUIS FERNANDO VALERO IGLESIAS EL CINE COMO INSTRUMENTO DE ALFABETIZACIÓN EMOCIONAL

GüEL, M. y MuÑoz, J. (2003) Educación emocional. Programa para la educación secundaria postobligatoria. Barcelona, Praxis.

GutiÉrRez MoAr, M. ${ }^{a}$ C. (1998) La afectividad y su educación en el ciclo 0-3, Revista de Innovación Educativa, 8, 243-247.

- (2002) El reto socioeducativo del binomio motivación-emoción para enseñar y aprender la capacitación emocional. Comunicación presentada al VIII Congreso de Educación Comparada. "Educación obligatoria en Europa y Latinoamérica. Situación actual y perspectivas de futuro. Celebrado en Salamanca (20-23 noviembre), Universidad de Salamanca.

- (2004) Afectividad y aprendizaje educativo: Hacia una Pedagogía de la prevención. Santiago de Compostela, Universidad de Santiago de Compostela. Facultad Ciencias de la Educación. (Tesis Doctoral publicada por la USC en formato CD-ROM con el ISBN 84-9750-325-2).

HerRnsteIn, R. J. y MurRaY, C. (1994) Inteligencia emocional. Barcelona, Kairós.

Hoyos, G. y MARTínez, M. (coords.) (2004) ¿Qué significa educar en valores boy? Barcelona, Octaedro-OEI.

Hueso, A. L. (1998) El cine y el siglo XX. Barcelona, Ariel.

Instituto PedAgógico PAdRes y MAestros (2003) Cine y transversales. Treinta películas para trabajar en el aula. Bilbao, Mensajero.

López, E. (2003) Educación emocional. Programa para 3-6 años. Barcelona, Praxis.

LORENTE, M. (2001) Mi marido me pega lo normal. Barcelona, Crítica.

- (2004) El rompecabezas. Anatomía del maltratador. Barcelona, Crítica.

LOSCERTAles, F. y NúÑEz, T. (2001) Violencia en las aulas. El cine como espejo social. Barcelona, Octaedro.

MaRINA; J. A. (2000) Teoria de la inteligencia creadora. Barcelona, Anagrama.

Marina, J. A. y López, M. (2001) Diccionario de los sentimientos. Barcelona, Anagrama.

Martínez, J. (coord.) (2003) Películas para usar en el aula. Madrid, Publicaciones UNED.

Martínez, M.; Puig, J. M. ${ }^{a}$ y Trilla, J. (2003) Escuela, profesorado y educación moral, Teoría de la Educación, 15, 57-94.

MarTínez López, M. (2005) Cómo favorecer el desarrollo emocional y social de la infancia: bacia un mundo sin violencia. Madrid, Los Libros de la Catarata.

Martínez-Salanova, E. (2002) Aprender con el cine, aprender de película. Una visión didáctica para aprender e investigar con el cine. Huelva, Grupo Comunicar Ediciones.

- (2003) El valor del cine para aprender y enseñar, Comunicar, 20, 45-52.

NAYA, L. M. (coord.) (2005) La educación y los derechos humanos. Universidad País VascoFundación Santa María, Eirin.

NúÑEZ, L. (2000) La escuela toma la palabra. Madrid, PPC.

Ortega, P. y Mínguez, R. (2003) Familia y transmisión de valores, Teoria de la Educación, 15, 33-56.

OrTigosa, S. (2002) La educación en valores a través del cine y las artes, Revista Iberoamericana, 29, 157-175.

Pascual, V. y Cuadrado, M. (2001) Educación emocional. Programa de actividades para educación secundaria obligatoria. Barcelona, Praxis.

Pereira, M. ${ }^{a}$ C. (2005a) Cine y Educación social, Revista de Educación, Monográfico: Educación No Formal, 338, 205-228.

- (2005b) Los valores del cine de animación. Propuestas pedagógicas para padres y educadores. Barcelona, PPU. 
Pereira, C. y Urpí, C. (2005) Cine y juventud: una propuesta integral, Revista de Estudios de Juventud, Monográfico: Jóvenes y medios de comunicación, 68, 75-89.

Prats, Ll. (2005) Cine para educar. Barcelona, Belacqua.

Punset, E. (2004) Cara a cara con la vida, la mente y el universo. Barcelona, Destino.

- (2005) El viaje a la felicidad. Las nuevas claves cientificas. Madrid, Destino.

RENOM, A. (2003) Educación emocional. Programa para la educación primaria. Barcelona, Praxis.

Rodríguez, M. ${ }^{a}$ C. y PeÑa, J. V. (2005) La investigación sobre el género en la escuela: nuevas perspectivas teóricas, Teoría de la Educación, 17, 25-48.

Rodríguez Neira, T. (1999) La cultura contra la escuela. Barcelona, Ariel.

RojAS, E. (1998) El bombre light. Una vida sin valores. Madrid, Espasa Calpe, Temas de Hoy.

Rubia, F. J. (2006) ¿Qué sabes de tu cerebro? Madrid, Espasa-Calpe, Temas de hoy.

SALOVEY, P. Y MAYER, J. D. (1990) Emotional intelligence, Imagination, cognition and personality, vol. 9 (3), 185-211.

Sarramona, J.; VÁzQuez, G. y Colom, A. J. (1998) Educación no formal. Barcelona, Ariel.

SARTORI, G. (1998) Homo videns, la sociedad teledirigida. Madrid, Taurus.

SASTRE, G. (2002) Resolución de conflictos y aprendizaje emocional: una perspectiva de género. Barcelona, Gedisa.

Segura, M. y ARCAS, M. (2003) Educar las emociones y los sentimientos. Madrid, Narcea.

StAHELIN, C. (1976) El arte del cine. Valladolid, Haraldo.

TARKOVSKI, A. (2002) Esculpir en el tiempo. Reflexiones sobre el arte, la estética y la poética del cine ( $6^{\mathrm{a}}$ edición). Madrid, Rialph.

TORRE, S. DE LA (1999) Aprender del conflicto en el cine. Barcelona, PPU.

- (2000) Estrategias creativas para educación emocional, Revista Española de Pedagogía, $217,543-572$.

TouRiÑÁn, J. M. (1997) La racionalidad de la intervención pedagógica: explicación y comprensión, Revista de Educación, 314, 157-186.

- (2004) La educación electrónica: un reto de la sociedad digital en la escuela, Revista Española de Pedagogía, 227, 31-56.

Ugarte, C. (2005) El Decenio de las Naciones Unidas para la educación en la esfera de los derechos humanos. 1995-2004. Perspectiva de futuro, Estudios sobre Educación, 8, 119-134.

VAILlANT, D. (1997) La evolución de la inteligencia bumana. Barcelona, Crítica.

VALERO, L. F. (1992) Aproximación a una educación en valores. Barcelona, PPU.

VAllés, A. y Vallés, C. (2003) Psicopedagogía de la inteligencia emocional. Valencia, Promolibro.

Vázquez Gómez, G. (1984) Educación de la afectividad, en García Carrasco, J. (coord.). Diccionario de Ciencias de la Educación. Teoria de la Educación. Madrid, Anaya. 